\title{
Company Size Effect in Innovative Performance
}

\author{
Clandia Maffini Gomes', Isak Kruglianskas², \\ Flávia Luciane Scherer ${ }^{1}$
}

\begin{abstract}
The study presents the result of a research that had the objective of evaluate the influence of the size of the company in the practices of management of external sources of technological information and the correspondent impacts of these practices in the innovation performance of the enterprise.. The survey was carried based on data collected from a set of Brazilian industrial companies that are considered innovative The analysis of the relation between the management of external sources of technological information and the performance, according to the size of the companies disclosed that although being limited to a smal number there are some significant differences in aspects related to the access to technology and the types of external sources of technological information used by the firms. Some significant differences between small and larger firms on how these managerial practices affect the innovative performance were also detected
\end{abstract}

Keywords: company; innovative performance; management; external sources; technological information.

\footnotetext{
' School of Business Administration Federal University of Santa Maria, I I84 Floriano Peixoto Street Santa Maria, RS, 97020770, Brazil, Telephax 55-I I-32209296, (Corresponding authors) E-mail: clandia@smail.ufsm.br, scherer@smail.ufsm.br

${ }^{2}$ School of Economics and Business Administration, University of São Paulo. 908 Luciano Gualberto Ave, São Paulo, SP 05508, Brazil. Telephax 55-I I-3032-4640. E-mail: ikruglia@usp.br
}

ISSN: 07I 8-2724. (http://www.jotmi.org)

Journal of Technology Management \& Innovation (c) Universidad Alberto Hurtado, Facultad de Economía y Negocios 


\section{Introduction}

This paper proposes to understand the process that concerns the management of sources of technological information and innovation performance. The focus is on practices adopted by businesses according to their size, and the objective is to create a theoretical and practical framework for the development of a sustainable technological innovation process.

The management of forms of access to technology and to sources of technological information and of the interfaces between the partners in the development of innovation expands business opportunities and improves performance. Businesses are strengthening their partnerships with the purpose of using external sources of information for innovation purposes; however, they still need a specific management strategy. (Linder, 2003)

At the same time, several researchers have been trying to prove the influence of the size of the businesses on the development of innovation-related activities, many of which are already known (Greve, 2008). Internally, large firms have more sophisticated and professional structures; as a result, decisions are made in a less bureaucratic manner and are less flexible in terms of change (Chen, 1995). Externally, large firms have stronger market power and have a stronger influence on the spreading of innovations (Boone, 2004).

Our survey was conducted at Brazilian firms from the industrial sector. The quantitative research sought to contribute to the inferences on the relationship between the management of external sources of technological information and the innovation performance of firms according to their size. To achieve this objective, we conducted analysis of the relationship between the independent and the dependent variables. The analysis of these firms' practices and the influence of their size on the course of the technological innovation process is a strategic issue for global competitiveness. An understanding of how large and small firms behave in relation to how innovation performance is managed leads to the possibility of developing strategies that drive business actions in each business segment.

\section{Theoretical Basis}

A core problem related to the optimization of the return on technological investment, according to Ford (1996), is that many firms deal with the analysis and implementation of the exploration of technology based on a restricted, in-house perspective. Few firms have a strategic view of external exploration or examine when and where they should sell their technology to other firms or cooperate with other firms in terms of exploring technology. There are many reasons for this restricted view of the exploration of technology, such as instructions from senior management with a narrow strategic view of the development and exploration of the firm's process and marketing technology; a business structure focused mainly on the products rather than on the exploration of the technology that the products are based on; inadequate accounting with few mechanisms to measure the return on technological investment; a mechanical approach that dedicates little attention to the strategic use of the technology underlying the products; and planning the life cycle without integrating the inputs of the different functional areas.

The firm's ability to acknowledge the value of new, outside information, assimilate it and apply it to its commercial purposes is critical for its innovation ability. The benefits derived from knowledge depend not only on the sagacity of the technology source but above all on the firm's ability to absorb the technology. Leonard-Barton (1995) states that firms differ considerably in terms of their ability to develop external knowledge, in other words, their ability to identify, access and assimilate knowledge from external sources of technological information.

The use of external sources of technological information will tend to grow significantly in the upcoming years. Corporations have shifted their innovation focus from using internal information sources to using external ones, such as consumers, surveys conducted by firms, business partners, and universities. Firms are now reducing the innovation activities based on internal sources, because of their involvement in venture capital, technological alliances or acquisitions. In spite of resorting to external sources of technological information, firms have no management strategy for these sources. A management strategy for information sources on innovation not only helps the firm decide on the combination of internal and external 
sources, but also helps it leverage current innovation. Few firms have a defined management strategy for information sources and manage the several sources in an integrated manner in order to achieve superior results (Linder, 2003).

Heightened global competion is leading firms to provide their products and services with shorter life cycles, which requires shorter and shorter development time, indicates Chatterji (1996). Firms are acknowledging that they have to obtain all kinds of technology sources - internal and external - to increase speed. The operating and cost margins are other factors that put pressure on the need for change. In addition, collaboration with external technology sources becomes an interesting option, as it raises the possibility of sharing investment risks.

The firm's ability to expand its knowledge on the basis of its use of external information sources derives from a combination of various relationships that can be formal or informal. These relationships can involve other firms, the collaboration between firms (consumers and suppliers), the spreading of technology among firms (departments of universities or laboratories from the public and private sectors) and the networking skills of research and development professionals to build up individual relationships with scientists and engineers from other firms and organizations. The specific focus of innovation at most firms is closely related to the individual responsibility rather than being related specifically to a corporate plan. The main advantages of using external sources of technological information are the creation of new opportunities, faster and more efficient results, lower innovation costs, easier priority definitions and encouragement of in-house innovation. (Beltramo, 2004).

Chatterji (1996) prepared a conceptual model for the management of external sources of technological information, which has become increasingly important for the expansion of a firm's innovation ability. Each firm should develop and use a set of management practices that meets its specific interests. Based on the results achieved in studies of this issue, the author prepared a list of good industrial practices available for firms interested in beginning or expanding the effects of using technology sources. The management of external sources of technological information must be developed and included in a management plan that comprises the efforts of internal or external sources. The successful use of external information sources requires a planned approach to manage a business process that has become increasingly important, with good practices emerging from the $R$ \& $D$ community. Firms interested in initiating or expanding efforts in the sense of resorting to external sources of technological information should resort to relevant practices that increase their innovation abilities.

According to Linder, Jarvenpaa (2003) the use of external sources of technological information involves some subtle and significant limitations, including culture, pace, the flow of information and work processes. Adopting a management strategy for information sources for innovation implies preparing an innovation management model that differs from the one adopted by most firms. With such a strategy, specialization in the marketing and management of innovation channels should be more relevant for the success of the innovation.

The main aspects that determine the innovation attitude of large or small firms are still relatively ill-known, due to the complexity of the process for the management of innovation-related activities. According to the theory of the firm, the corporate decision making process is based on multiple factors that result in internal bargaining and in objectives and aspirations that guide corporate actions. This objective encompasses the level of aspiration in relation to the measuring of corporate performance (Greve, 2008).

The predominant management outlook is based on the belief that the size of a firm affects corporate efficiency and legitimacy. The definition of the size of a firm influences its business strategy. Corporations respond to a reduction in low performance by preparing strategic and operating changes, including entry into new markets, by acquiring external resources, and by improving their $R$ \& $D$ and innovation capabilities (Greve, 2008).

Several studies have analyzed the relationship between the size of the firm and innovative performance. According to some researchers, larger firms engage more strongly in innovation. Some economists argue that, under perfect competitive conditions, firms would be more motivated to be innovative. Other researchers argue that both large and 
small firms have advantages and disadvantages in the innovation process (Macedo 1999).

Regardless of size, the prospect of establishing an external relationship with other firms gives rise to significant implications for a firm's performance. Zaheer (2005) did some research into whether firms with a stronger network structure are more skillful at exploiting their internal capabilities to improve their performance. The results of their study showed that a firm's ability to innovate does not improve its performance directly; however, innovative firms that have this network structure improve their performance.

According to McEvily (1999), studies often consider the effects of networking - more specifically, of their partners or structure - on performance. The goodwill of a firm results from its contacts, as well as from the research controlled by these contacts, the firm's ability to explore this research, and the ties built up by partnerships.

Firms vary in their capability to develop, understand or use innovation and knowledge. The key factor for the improvement of a firm's capability to use and benefit from the knowledge acquired externally is its absorption capacity, which is often reflected in its ability to innovate and in the skill in exploring new knowledge. (Cohen ,1990). Internal communication and cultural issues are factors that additionally influence the ability to innovate. (Chandy, 1998).

A study conducted by Cohen (1990) concluded that the capacity to absorb is critical for a firm's innovative capability. Absorption capacity can be defined as a firm's ability to recognize the value of new and external information, to analyze it and to apply it for commercial purposes. Firms with a high absorption capacity tend to be proactive and skillful in terms of exploring opportunities; firms with low absorption capacity tend to be more reactive. (Darso, 200I).

According to Costa (200I), technological capability can be measured by means of different indicators, but all of them refer to infrastructure, to the training of the human resources involved in $R$ \& $D$, to external sources of technology acquisition and to the results achieved. A study conducted with the metallurgy, mechanic and electrical goods industries identified industrial automation, the ability to generate technology, the number of employees involved in $R \& D$, the importance attributed to $R \& D$, and the \% of annual revenues invested in $R \& D$ as the main indicators.

One of the chief difficulties for an analysis of the innovative behavior of firms resides in the availability of data. According to Sbragia (1998), the indicators presented by several countries are rather incipient and limited. Several international institutions have been trying to create and define common indicators.

The aforementioned concepts and indicators reveal the increasing importance for firms of creating evaluation mechanisms for innovation activities as a way of ensuring company growth and competitiveness. Analyzing the behavior of firms by size regarding innovation activity and performance allows for the verification of specificities that are inherent to every kind of organization. The identification of these singularities points out the need to create and use indicators that are aligned with the business realities that maximize innovation ability and performance.

\section{Methodology}

The quantitative study involved conducting a survey. According to Babbie (1999), surveys are conducted to obtain descriptive facts about a given population. To this end, we used a data collection mechanism applied to Brazilian firms from the industrial sector. The objective was to identify the behavior of firms concerning the management of sources of information for the innovation and innovation performance of firms, according to their size.

\section{I Research framework}

Based on the study's objectives, the concepts and information obtained from the theoretical base led to the creation of a conceptual model as a reference for the conduction of the study. The said conceptual model is shown in Figure I. 


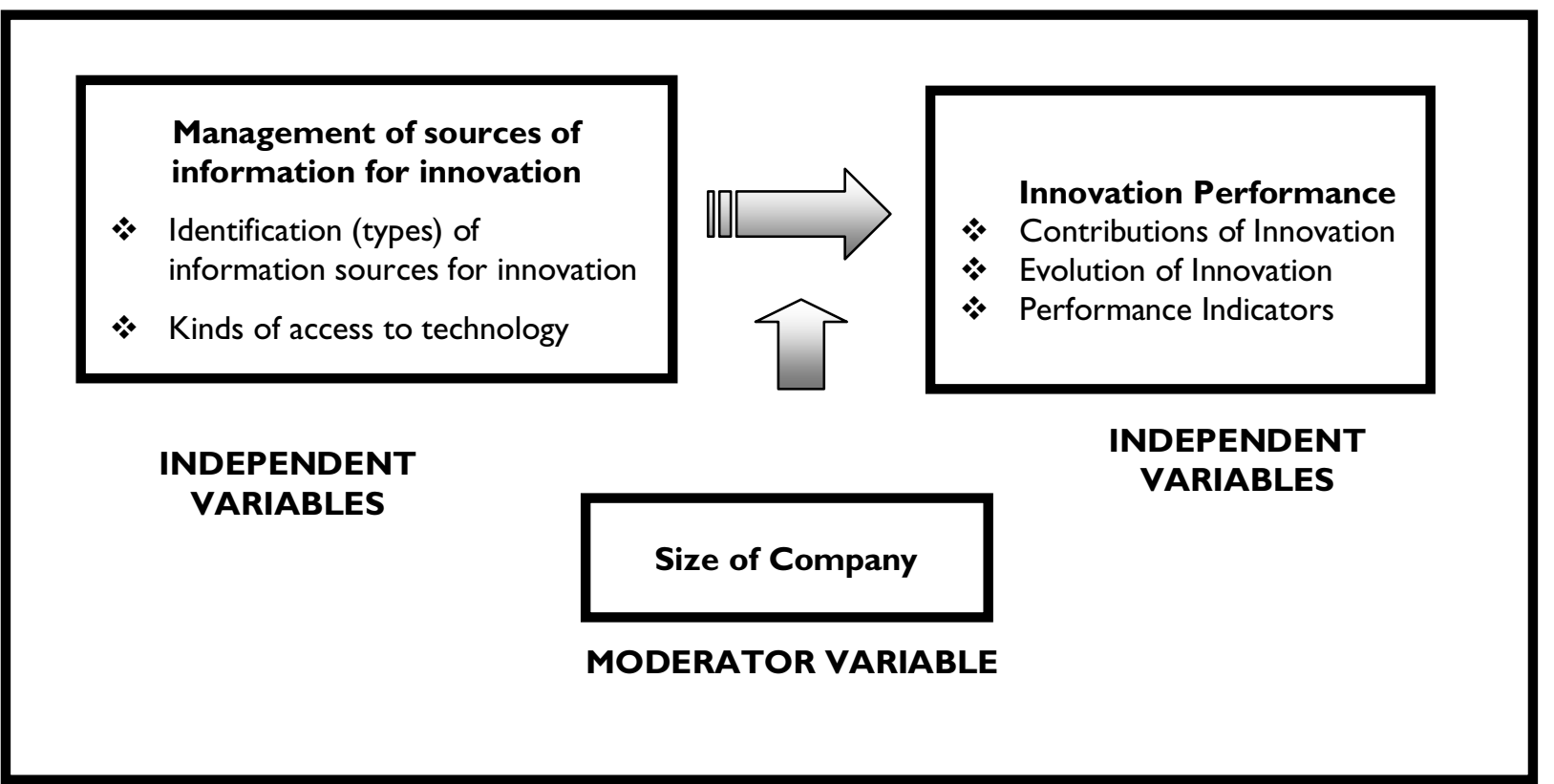

Figure I. Conceptual Model of the Study

In Figure I, the dependent, independent and moderator variables characterized by their indicators (sub-variables, to be presented further ahead), corresponded to the following concepts:

a) Identification (types) of information sources for innovation: they correspond to different institutional, personal and opportunistic alternatives that firms can resort to for accessing the information that drives their innovation process.

b) Kinds of access to technology: in a way, this variable complements the previous one and refers to the approaches that firms use to coordinate actions that allow them to take advantage of opportunities, so as to ensure the efficient and systematic use of sources of information.

c) Innovation contributions: this dependent variable is related to aspects of technological innovation contributions to products and processes, as well as to the technological skills of the firm.

d) Evolution of innovation performance indicators: this other variable measures the pace of the evolution of some critical innovation performance indicators over a period of time (in a five-year period)

e) Firm size: this moderator variable differentiates researched firms according to the number of employees.

The proposed conceptual model is based on several presuppositions. The main is that there is the influence of the size of the businesses on the development of the management of external sources of technology information and of the innovative performance.

\subsection{Procedures for gathering and analyzing the data}

The study focused on Brazilian firms from the industrial sector with characteristics and signs of emphasis on innovation. This population was chosen as the object of investigation because the management of outside sources of technology information is most common in this type of company. The registry of companies for the study was comprised of firms that are members of ANPEl, Brazil's National Association of Research, Development and Engineering of Innovative Firms, and of the PGT Technological Management Program of the FIA Administration Institute Foundation. 
The questionnaire sent to these companies was specifically addressed to the person responsible for the area of technology, and to officers or CEOs of the member companies of ANPEI and PGT. The questionnaire was sent by e-mail and through access to a website. The total number of replies obtained was considered high in terms of the basic list used. Of a total of 191 companies, 72 answered and returned the questionnaire, representing approximately $38 \%$ of the companies that received the first e-mail.

The data was processed with the aid of Microsoft Excel and SPSS software programs. To perform the analysis, unvaried $(\mu)$ and bivariate ( $\chi 2$ Test) analyses were carried out through the statistical techniques of factor analysis.

\section{Analysis of the results}

Based on the data obtained through the survey, we then conducted the analysis. We first analyzed the characteristics of the profiles of the firms in the sample. This is followed by the values of the variables related to the management of the sources of technological information and the values of the variables that comprise innovation performance, according to the size of the firms.

\section{I Profile of the respondents}

The profile of the respondents is specified in Table I.

\begin{tabular}{|c|c|}
\hline \multicolumn{2}{|c|}{ Characteristics of the research's respondents } \\
\hline I. Average Period of Time Working for the Company & 13.59 years \\
\hline 2. University Degree & 13 \\
\hline 3. Post-Graduate Degree & 59 \\
\hline
\end{tabular}

Table I. Time working for the firm and professional background of the respondents

\subsection{Profile of the researched firms}

\section{a) Activity sector}

The data related to the activity sector of the researched firms is specified in Table 2 and 3.

\begin{tabular}{l|c|c}
\hline \multicolumn{1}{c|}{ Activity Sector } & Frequency & $\%$ \\
\hline Office/Information Technology Material & $\mathrm{I}$ & $\mathrm{I}$ \\
\hline Instruments, Optical Instruments and Automation Equipment & 2 & 2.8 \\
\hline Electronic and Telecommunications Material & 7 & 9.7 \\
\hline Chemicals & 7 & 9.7 \\
\hline Machines and Equipment & 5 & 6.9 \\
\hline Other Transportation Equipment & $\mathrm{I}$ & $\mathrm{I}$ \\
\hline Rubber/Plastics & 2 & 2.8 \\
\hline Vehicles/Car Parts & 7 & 9.7 \\
\hline Oil/Ethanol Refining & $\mathrm{I}$ & 1.4 \\
\hline Electrical Material & $\mathrm{I}$ & 1.4 \\
\hline
\end{tabular}

(Continued on next page) 


\begin{tabular}{l|c|c}
\multicolumn{2}{|c}{ (Continued from previous page) } \\
\hline Basic Metallurgy & $\mathrm{I}$ & $\mathrm{I} .4$ \\
\hline Metal Products (except for machines and equipment) & 2 & 2.8 \\
\hline Pulp/Paper & 3 & 4.2 \\
\hline Non-Ferrous Metals & $\mathrm{I}$ & 1.4 \\
\hline Food Products/Beverages & 3 & 4.2 \\
\hline Mining & 3 & 4.2 \\
\hline Other Sectors & 25 & 34.7 \\
\hline Total & 72 & 100 \\
\hline
\end{tabular}

Table 2. Activity Sector

\begin{tabular}{l|c|c}
\multicolumn{1}{c|}{ Number of Employees } & Frequency & $\%$ \\
\hline Up to 99 employees (small firm) & 11 & 15.3 \\
\hline From 100 to 499 employees (medium-sized firm) & 14 & 19.4 \\
\hline More than 500 employees (big firm) & 47 & 65.3 \\
\hline Total & 72 & 100 \\
\hline
\end{tabular}

Table 3. Number of Employees

\section{b) Gross Operating Income}

The gross operating income, according to the number of employees employed by the researched firms, is listed in Table 4.

\begin{tabular}{|c|c|c|}
\hline Gross Operating Income in Reals (2005)* & Frequency & $\%$ \\
\hline Up to 720,000 & 4 & 5.6 \\
\hline From $3,000,00 \mathrm{I}$ to $7,875,000$ & 5 & 6.9 \\
\hline From $7,875,00$ I to $20,000,000$ & 2 & 2.8 \\
\hline From $20,000,00$ I to $70,000,000$ & 5 & 6.9 \\
\hline From $70,000,00 \mid$ to $150,000,000$ & 6 & 8.3 \\
\hline From $|50,000,00|$ to $400,000,000$ & 8 & II.I \\
\hline More than $400,000,001$ & 39 & 54.2 \\
\hline No response & 3 & 4.2 \\
\hline Total & 72 & 100 \\
\hline
\end{tabular}

Table 4 - Gross Operating Income 
c) Origin of controlling shareholders' capital, shareholding stake and nationality of foreign capital

The data related to the origin of the controlling shareholders' capital, the shareholding stake held by

foreign capital, the nationality of the foreign capital and the percentage of exports in the firm's gross operating income is listed in Table 5.

\begin{tabular}{l|cc}
\hline \multicolumn{1}{c|}{ Origin of controlling shareholders' capital } & Frequency & $\%$ \\
\hline National & 43 & 59.7 \\
Foreign & 24 & 33.3 \\
No response & 5 & 6.9 \\
Total & 72 & 100 \\
\hline
\end{tabular}

Table 5. Origin of Controlling Shareholders' Capital, Shareholding Stake and Nationality of Foreign Capital

To stratify the sample, we resorted to the moderator variable as dichotomy, the values of which were attributed as instructed by the IBGE. The values of this variable are listed in Table 6.

\begin{tabular}{l|c|c}
\hline \multicolumn{1}{c|}{ Size of the Firms } & Frequency & $\%$ \\
\hline Smaller size (up to 499 employees) & 25 & 34.7 \\
\hline Larger size (more than 499 employees) & 47 & 65.3 \\
\hline Total & 72 & 100 \\
\hline
\end{tabular}

Table 6. Size of the firms

The average profile of the firms after the stratification of the sample by the moderator variable is shown in Table 7 .

\begin{tabular}{|c|c|c|}
\hline Indicator & Smaller & Larger \\
\hline Activity Sector & $\begin{array}{l}\text { Instruments, Optical Instruments and } \\
\text { Automation Equipment, Chemicals, } \\
\text { Rubber/Plastics }\end{array}$ & $\begin{array}{l}\text { Electronic and Telecommunications } \\
\text { Equipment. Vehicles/Car Parts, and } \\
\text { Machines and Equipment }\end{array}$ \\
\hline Number of employees & From 100 to 499 employees & More than 2,000 employees \\
\hline Gross Operating Income & Up to $150,000,000$ reals & Higher than $1,000,000,000$ \\
\hline $\begin{array}{l}\text { Origin of controlling } \\
\text { shareholders' capital }\end{array}$ & National & National (49\%) and Foreign (45\%) \\
\hline $\begin{array}{l}\text { Shareholding stake held by } \\
\text { foreign capital }\end{array}$ & $\begin{array}{l}\text { No shareholding stake held by foreign } \\
\text { capital }\end{array}$ & Higher than $50 \%$ (Europe, Asia and USA) \\
\hline
\end{tabular}

(Continued on next page) 


\begin{tabular}{|l|l|l|}
\hline $\begin{array}{l}\text { Percentage of exports in gross } \\
\text { operating income }\end{array}$ & $\begin{array}{l}\text { The majority of the firms are not in the } \\
\text { export business (maximum up to 10\%) }\end{array}$ & (Continued from previous page) \\
\hline $\begin{array}{l}\text { Type of innovation } \\
\text { Main responsibility for } \\
\text { innovation activity }\end{array}$ & The firm & $\begin{array}{l}\text { The firm in cooperation with other firms } \\
\text { and/or institutions and universities }\end{array}$ \\
\hline $\begin{array}{l}\text { Main Department (sector }- \\
\text { responsible for the } \\
\text { management of innovation } \\
\text { activities ) }\end{array}$ & Executive officers or R \& D Managers & Executive officers or R \& D Managers \\
\hline
\end{tabular}

Table 7. Profile of researched firms, according to size

\subsection{Analysis of the values of the independent} variables

The management of sources of technological information is characterized on the basis of the evaluation of the intensity of use in relation to the kinds of access to types of technology and to the types of sources of technological information. The values of these variables, considering both the complete survey and the stratification by size, are shown in Tables 8, 9, 10 e II.

The values of the indicators of the intensity of use of the various kinds of access to technology variable for the group of firms that were part of the survey are shown in terms of relative frequency (\%) in Table 8.

\begin{tabular}{|c|c|c|c|c|c|c|c|}
\hline \multirow[b]{2}{*}{ Kinds of Access } & \multicolumn{7}{|c|}{ Intensity (\%) } \\
\hline & $\begin{array}{c}\text { NR } \\
\text { No } \\
\text { Response }\end{array}$ & $\begin{array}{c}\text { VLow } \\
\text { (I) }\end{array}$ & $\begin{array}{l}\text { Low } \\
\text { (2) }\end{array}$ & $\begin{array}{c}\text { Mean } \\
(3)\end{array}$ & $\begin{array}{l}\text { High } \\
\text { (4) }\end{array}$ & $\begin{array}{c}\text { VHigh } \\
\text { (5) }\end{array}$ & Total \\
\hline Purchases per Specification & 15.3 & 6.9 & 9.7 & 20.8 & 23.6 & 23.6 & 100 \\
\hline Partnership with suppliers & 15.3 & 5.6 & 15.3 & 23.6 & 29.2 & II.I & 100 \\
\hline Universities & 8.3 & 11.1 & 8.3 & 27.8 & 29.2 & 15.3 & 100 \\
\hline Retaining of Consulting Services & 9.7 & 18.1 & 16.7 & 25 & 26.4 & 4.2 & 100 \\
\hline Partnership with other firms & 16.7 & 16.7 & 11.1 & 22.2 & 22.2 & II.I & 100 \\
\hline Special Interest forums & 23.6 & 16.7 & 19.4 & 15.3 & 20.8 & 4.2 & 100 \\
\hline Outsourcing & 25.0 & 22.2 & 13.9 & 22.2 & II.I & 5.6 & 100 \\
\hline Purchases from Catalogues & 23.6 & 40.3 & 16.7 & 11.1 & 6.9 & 1.4 & 100 \\
\hline Partnership with Competitors & 37.5 & 37.5 & 20.8 & 4.2 & - & - & 100 \\
\hline Acquisition of License & 31.9 & 34.7 & 18.1 & 9.7 & - & 5.6 & 100 \\
\hline
\end{tabular}




\begin{tabular}{|l|c|c|c|c|c|c|c|}
\hline Venture capital & 56.9 & 30.6 & 8.3 & 2.8 & - & 1.4 \\
\hline Venture Capital Investment & 51.4 & 30.6 & 8.3 & 5.6 & 2.8 & 1.4 & 100 \\
\hline Pool of Firms & 37.5 & 29.2 & 12.5 & 12.5 & 6.9 & 1.4 & 100 \\
\hline Licensing & 31.9 & 27.8 & 6.9 & 16.7 & 11.1 & 5.6 & 100 \\
\hline Joint venture & 51.4 & 27.8 & 8.3 & 5.6 & 4.2 & 2.8 & 100 \\
\hline Acquisition of patents & 44.4 & 27.8 & 18.1 & 8.3 & - & 1.4 & 100 \\
\hline Acquisition of firms & 36.1 & 23.6 & 15.3 & 18.1 & 5.6 & 1.4 & 100 \\
\hline Outsourced R\&D & 33.3 & 23.5 & 11.1 & 13.9 & 12.5 & 5.6 & 100 \\
\hline Cooperation Networks & 29.2 & 20.8 & 12.5 & 18.1 & 9.7 & 9.7 & 100 \\
\hline Strategic Alliance & 36.1 & 19.4 & 15.3 & 16.7 & 5.6 & 6.9 & 100 \\
\hline
\end{tabular}

Table 8. Kinds of Access to Technology Modalities

The analysis of the data resulting from the research, as shown in Table 8, indicates that firms use purchases according to specifications as access to technology. The data also reveals, quite convincingly, that the respondent firms do not emphasize access to types of technology based on collaborative work with third parties, which is worrisome, given the growing tendency of the business world to lean toward so-called open innovation.
Table 9 shows the values of the access to types of technology variable with the sample stratified according to size. The values shown correspond to the verified mean value (on a scale from I to 5 , where the lowest value corresponds to lower intensity in terms of using the source). To facilitate the analysis, the data are shown in decreasing order of intensity in terms of use, the reference being the large firms and $\mathrm{N}$ the $\mathrm{nr}$. of firms.

\begin{tabular}{|c|c|c|c|c|c|}
\hline \multirow{3}{*}{ Kinds of Access } & \multicolumn{4}{|c|}{ Descriptive Measurements } & \multirow{3}{*}{$\begin{array}{r}x 2 \text { Test } \\
{ }^{*} p<0.05 \\
* * p<0.01\end{array}$} \\
\hline & \multicolumn{2}{|c|}{ Smaller } & \multicolumn{2}{|c|}{ Larger } & \\
\hline & $\mathrm{N}$ & Mean & $N$ & Mean & \\
\hline Universities & 21 & 3.43 & 45 & 3.27 & 0.619 \\
\hline Partnership with suppliers & 18 & 3.44 & 43 & 3.23 & 0.503 \\
\hline Retaining of Consulting firms & 21 & 2.67 & 44 & 2.86 & $0.54 I$ \\
\hline Partnership with other firms & 19 & 3.42 & 41 & 2.80 & 0.095 \\
\hline Special interest forums & 17 & 2.47 & 38 & 2.79 & 0.385 \\
\hline Outsourced R\&D & 16 & 2.50 & 32 & 2.47 & $0.94 I$ \\
\hline Cooperation Networks & 17 & 3.06 & 34 & 2.44 & 0.138 \\
\hline Outsourcing & 17 & 2.76 & 37 & 2.41 & 0.339 \\
\hline Licensing & 16 & 2.56 & 33 & 2.33 & 0.592 \\
\hline Strategic Alliance & 16 & 2.75 & 30 & 2.30 & 0.273 \\
\hline
\end{tabular}

(Continued on next page) 


\begin{tabular}{|l|c|c|c|c|c|}
\hline Pool of firms & 14 & 1.50 & 31 & 2.26 & $0.04 I^{*}$ \\
\hline Acquisition of firms & 11 & 2.27 & 35 & 2.11 & 0.680 \\
\hline Purchases according to specifications & 23 & 3.30 & 38 & 1.85 & 0.220 \\
\hline Joint venture & 12 & 2.00 & 23 & 1.83 & 0.703 \\
\hline Acquisition of license & 13 & 1.54 & 27 & 1.81 & 0.373 \\
\hline Acquisition of patent & 17 & 2.12 & 32 & 1.75 & 0.306 \\
\hline Investment in venture capital & 11 & 1.91 & 24 & 1.58 & 0.415 \\
\hline Partnership with competitors & 13 & 1.38 & 32 & 1.50 & $0.58 \mathrm{I}$ \\
\hline Venture capital & 11 & 1.45 & 20 & 1.45 & 0.989 \\
\hline
\end{tabular}

Table 9. Kinds of access to types of technology, according to size

The comparison of the data in Table 9, which is a comparison of large and small firms, shows that the behavior of firms from both groups concerning access to technology is very similar. Universities are a kind of access to technology; resorting to a pool of firms is the only kind of access to technology that significantly differentiates small and large firms, even firms rarely resort to it. This seems to be reasonably acceptable, given the limitations faced by small firms to manage this kind of access to technology.

The values of the variable related to the intensity of use of the various types of sources of information for innovation for the group of firms that comprised the survey are specified in terms of relative frequency (\%) in Table 10.

\begin{tabular}{|c|c|c|c|c|c|c|c|}
\hline \multirow{2}{*}{ Sources of information } & \multicolumn{7}{|c|}{ Intensity (\%) } \\
\hline & $\begin{array}{c}\text { NR } \\
\text { No. } \\
\text { response. }\end{array}$ & VLow & Low & Mean & High & VHigh & Total \\
\hline R\&D Department & 5.6 & 2.8 & 8.3 & 6.9 & 22.2 & 54.2 & 100 \\
\hline Visits to other firms of the group & 26.4 & 13.9 & 12.5 & 15.3 & 13.9 & 18.1 & 100 \\
\hline Other departments & 6.9 & 5.6 & 4.2 & 26.4 & 44.4 & 12.5 & 100 \\
\hline Suppliers & 9.7 & 5.6 & 12.5 & 16.7 & 40.3 & 15.3 & 100 \\
\hline Trade fairs and expositions & 1.4 & 4.2 & 12.5 & 27.8 & 37.5 & 16.7 & 100 \\
\hline $\begin{array}{l}\text { Universities/Higher Learning } \\
\text { Centers }\end{array}$ & 4.2 & 6.9 & 13.9 & 22.2 & 33.3 & 19.4 & 100 \\
\hline Adoption of technical standards & 13.9 & 12.5 & 11.1 & 18.1 & 30.6 & 13.9 & 100 \\
\hline Technical and scientific publications & 1.4 & 5.6 & 15.3 & 27.8 & 29.2 & 20.8 & 100 \\
\hline Clients & 6.9 & 5.6 & 19.4 & 20.8 & 27.8 & 19.4 & 100 \\
\hline Network & 9.7 & 12.5 & 13.9 & 22.2 & 25 & 16.7 & 100 \\
\hline
\end{tabular}

(Continued on next page) 


\begin{tabular}{|c|c|c|c|c|c|c|c|}
\hline & & & & & \multicolumn{3}{|c|}{ (Continued from previous page) } \\
\hline Research institutes & 8.3 & 9.7 & 23.6 & 13.9 & 23.6 & 20.8 & 100 \\
\hline Visits to other firms /licensors & 13.9 & 19.4 & 11.1 & 31.9 & 15.3 & 8.3 & 100 \\
\hline Scientific/professional conferences & 4.2 & 8.3 & 11.1 & 29.2 & 26.4 & 20.8 & 100 \\
\hline Scientific/professional associations & 8.3 & 9.7 & 23.6 & 25 & 23.6 & 9.7 & 100 \\
\hline $\begin{array}{lll}\text { InfoTech } & \text { networks } & \text { (on-line } \\
\text { databases) } & & \\
\end{array}$ & 8.3 & 12.5 & 19.4 & 25 & 20.8 & 13.9 & 100 \\
\hline Consumers & 20.8 & 16.7 & 16.7 & 20.8 & 11.1 & 13.9 & 100 \\
\hline Hiring of external talent & 13.9 & 19.4 & 31.9 & 22.2 & 9.7 & 2.8 & 100 \\
\hline $\begin{array}{ll}\text { Consulting } & \text { firms/independent } \\
\text { consultants } & \end{array}$ & 8.3 & 11.1 & 29.2 & 27.8 & 15.3 & 8.3 & 100 \\
\hline Competitors & 15.3 & 8.3 & 27.8 & 18.1 & 25 & 5.6 & 100 \\
\hline Community of practices & 40.3 & 22.2 & 26.4 & 5.6 & 2.8 & 2.8 & 100 \\
\hline $\begin{array}{l}\text { Institutional tests, essays and } \\
\text { certifications }\end{array}$ & II.I & 6.9 & 26.4 & 25 & 20.8 & 9.7 & 100 \\
\hline Other firms of the group & 30.6 & 9.7 & 19.4 & 12.5 & 16.7 & 11.1 & 100 \\
\hline$R \& D$ of other firms & 20.8 & 29.2 & 20.8 & 18.1 & 9.7 & 1.4 & 100 \\
\hline Professional training centers & 13.9 & 29.2 & 27.8 & 19.4 & 8.3 & 1.4 & 100 \\
\hline Contracted/outsourced firms & 22.2 & 27.8 & 20.8 & 19.4 & 4.2 & 5.6 & 100 \\
\hline Community networks & 40.3 & 27.8 & 25 & 4.2 & 1.4 & 1.4 & 100 \\
\hline $\begin{array}{l}\text { Acquisitions, licenses, patents, } \\
\text { know-how }\end{array}$ & 29.2 & 25 & 19.4 & II.I & 11.1 & 4.2 & 100 \\
\hline Leader Users & 45.8 & 23.6 & 11.1 & 6.9 & 8.3 & 4.2 & 100 \\
\hline Others & 86.1 & 5.6 & 2.8 & 1.4 & 1.4 & 2.8 & 100 \\
\hline
\end{tabular}

Table 10. Types of information sources for the innovation activity in decreasing order of intensity of use

The data in Table 10 is very rich regarding possible discussions or reflections, which, for reasons of space, cannot be explored in this paper. However, we must emphasize that R\&D is the main source of information that is used, which is very positive, as it suggests that Brazilian firms are maturing in terms of acknowledging the importance of R\&D. This is consistent with the literature and the practices of firms from developed countries.
The data in Table II evaluates the values of the variable related to the type of information sources used by smaller or larger firms, by measuring the intensity with which they said sources are used. The values in the table correspond to the mean value found (on a scale of $I$ to 5 , where the lowest value corresponds to the lowest intensity of use of the source). To facilitate the analysis, the data are shown in decreasing order of intensity of use, the reference being the large firms an $\mathrm{N}$ being the absolute frequency. 


\begin{tabular}{|c|c|c|c|c|c|}
\hline \multirow{3}{*}{ Sources of information } & \multicolumn{4}{|c|}{ Descriptive Measurements } & \multirow{3}{*}{$\begin{array}{l}x 2 \text { Test } \\
* p<0.05 \\
* * p<.01\end{array}$} \\
\hline & \multicolumn{2}{|c|}{ Smaller } & \multicolumn{2}{|c|}{ Larger } & \\
\hline & $\mathrm{N}$ & Mean & $\mathrm{N}$ & Mean & \\
\hline R\&D Department & 23 & 4.22 & 45 & 4.24 & 0.925 \\
\hline Professional/scientific conferences & 24 & 3.17 & 45 & 3.56 & 0.204 \\
\hline Other departments & 21 & 3.67 & 46 & 3.54 & 0.639 \\
\hline Universities and centers of higher education & 23 & 3.35 & 46 & 3.52 & 0.569 \\
\hline Technical and scientific publications & 25 & 3.32 & 46 & 3.52 & 0.486 \\
\hline Trade fairs and expositions & 25 & 3.52 & 46 & 3.50 & 0.940 \\
\hline Suppliers & 21 & 3.62 & 44 & 3.48 & 0.637 \\
\hline Adoption of technological standards & 22 & 3.09 & 40 & 3.35 & 0.455 \\
\hline Research institutes & 21 & 3.05 & 45 & 3.33 & 0.427 \\
\hline Visits to other firms and licensors & 13 & 2.62 & 40 & 3.30 & $0.007^{* *}$ \\
\hline Professional/scientific associations & 22 & 2.45 & 44 & 3.27 & $0.007^{* *}$ \\
\hline Network & 22 & 3.14 & 43 & 3.26 & 0.730 \\
\hline Clients & 24 & 3.75 & 43 & 3.19 & 0.066 \\
\hline Networks (on-line databases) & 23 & 2.96 & 43 & 3.09 & 0.681 \\
\hline Competitors & 21 & 2.57 & 40 & 3.08 & 0.100 \\
\hline Visits to other firms of the group & 19 & 2.16 & 43 & 3.07 & 0.142 \\
\hline Institutional tests, essays and certifications & 24 & 2.96 & 40 & 3.03 & 0.823 \\
\hline Other firms of the group & 13 & 3.15 & 37 & 2.95 & 0.631 \\
\hline Consulting firms & 22 & 2.73 & 44 & 2.82 & 0.763 \\
\hline Consumers & 20 & 2.95 & 37 & 2.81 & 0.066 \\
\hline Contracted/outsourced firms & 17 & 1.65 & 39 & 2.46 & $0.018^{*}$ \\
\hline Hiring of external talents & 21 & 2.38 & 41 & 2.34 & 0.891 \\
\hline Acquisition, licenses, patents, know-how & 16 & 2.25 & 35 & 2.31 & 0.869 \\
\hline Professional training centers & 21 & 2.10 & 41 & 2.15 & 0.858 \\
\hline Leader users & 13 & 2.38 & 26 & 2.15 & 0.625 \\
\hline R\&D of other firms & 20 & 2.25 & 37 & 2.11 & $0.65 I$ \\
\hline Community of practices & 13 & 1.92 & 30 & 1.97 & 0.902 \\
\hline Community networks & 13 & 1.77 & 30 & 1.70 & 0.816 \\
\hline
\end{tabular}

Table II. Types of sources of technological information 
The data in Table II shows that the main sources of technological information used by firms, regardless of their size, are similar. In line with what was previously discussed concerning small and large firms, R\&D is the source most often used for information that drives technological innovation.

Small firms resort less strongly to only three types of sources of information: visits to firms of the same group, institutional tests, learning and certifications, and finally, contracted/outsourced firms.

\subsection{Analysis of the values of the dependent variables}

The firms' performance according to their size is evaluated through an analysis of the impact of the innovation activity and of the evolution of the main indicators of the innovation activity.

The values of the indicators of the dependent variable related to contributions of the innovation activity to the group of firms participating in the survey are shown in terms of relative frequency (\%) in Table 12.

\begin{tabular}{|c|c|c|c|c|c|c|c|}
\hline \multirow{2}{*}{$\begin{array}{l}\text { Types of Impacts of the } \\
\text { Innovation Activities } \\
\text { (contributions) }\end{array}$} & \multicolumn{7}{|c|}{ Intensity of the Impact of the Innovation activities (\%) } \\
\hline & $\begin{array}{l}\text { NR } \\
\text { No } \\
\text { Response }\end{array}$ & $\begin{array}{l}\text { VLow } \\
\text { (I) }\end{array}$ & $\begin{array}{l}\text { Low } \\
\text { (2) }\end{array}$ & $\begin{array}{l}\text { Mean } \\
\text { (3) }\end{array}$ & $\begin{array}{l}\text { High } \\
\text { (4) }\end{array}$ & $\begin{array}{l}\text { VHigh } \\
\text { (5) }\end{array}$ & Total \\
\hline $\begin{array}{l}\text { Expansion of the scope of } \\
\text { products }\end{array}$ & 9.7 & 1.4 & 9.7 & 16.7 & 30.6 & 31.9 & 100 \\
\hline Improvement of product quality & 8.3 & - & 4.2 & 12.5 & 47.2 & 27.8 & 100 \\
\hline Increase of output capacity & II.I & - & 13.9 & 20.8 & 41.7 & 12.5 & 100 \\
\hline $\begin{array}{l}\text { Improvement of production } \\
\text { flexibility }\end{array}$ & 11.1 & - & 8.3 & 29.2 & 40.3 & 11.1 & 100 \\
\hline Entry into new markets & 13.9 & 1.4 & 2.8 & 16.7 & 37.5 & 27.8 & 100 \\
\hline Increase of firm's market share & 12.5 & - & 5.6 & 18.1 & 36.1 & 27.8 & 100 \\
\hline Reduction of production costs & 9.7 & 2.8 & 8.3 & 23.6 & 34.7 & 20.8 & 100 \\
\hline $\begin{array}{l}\text { Improvement in aspects } \\
\text { associated with the rules and } \\
\text { regulations of the domestic } \\
\text { market }\end{array}$ & 9.7 & 9.7 & 16.7 & 15.3 & 33.3 & 15.3 & 100 \\
\hline $\begin{array}{l}\text { Improvement in aspects } \\
\text { associated with the rules and } \\
\text { regulations of the foreign market }\end{array}$ & 16.7 & 6.9 & 16.7 & 13.9 & 30.6 & 15.3 & 100 \\
\hline $\begin{array}{l}\text { Improvement of aspects } \\
\text { associated with safety or health }\end{array}$ & 13.9 & 5.6 & 13.9 & 20.8 & 27.8 & 18.1 & 100 \\
\hline $\begin{array}{l}\text { Reduction of environmental } \\
\text { impact }\end{array}$ & 12.5 & 5.6 & 9.7 & 30.6 & 29.2 & 12.5 & 100 \\
\hline
\end{tabular}

Table 12. Contributions of innovation activity in decreasing order of intensity 
Table 13 identifies the qualitative impacts of the innovation activities in large and small firms in decreasing order of intensity of occurrence, the reference being the large firms and $\mathrm{N}$ the absolute frequency. The values correspond to the mean value (on a scale from I to 5 , where the lower value corresponds to the lower intensity of use of the source). To facilitate the analyses, the data are shown in decreasing order, the reference being the large firms.

\begin{tabular}{|c|c|c|c|c|c|}
\hline \multirow[t]{3}{*}{ Types of Contributions } & \multicolumn{4}{|c|}{$\begin{array}{l}\text { Intensity of occurrence of the contributions in } \\
\text { mean values * }\end{array}$} & \multirow[t]{3}{*}{$\chi^{2}$ Test } \\
\hline & \multicolumn{2}{|c|}{ Smaller } & \multicolumn{2}{|c|}{ Larger } & \\
\hline & $\mathrm{N}$ & & $\mathrm{N}$ & Mean & \\
\hline Entry into new markets & 23 & 4.00 & 39 & 4.03 & 0.914 \\
\hline Increase of market share & 22 & 3.95 & 41 & 4.00 & 0.848 \\
\hline Improvement of product quality & 24 & 4.25 & 42 & 3.98 & 0.178 \\
\hline Expansion of range of products & 23 & 3.83 & 42 & 3.95 & 0.649 \\
\hline Reduction of production costs & 22 & $3.4 I$ & 43 & 3.84 & 0.113 \\
\hline Improvement of production flexibility & 22 & 3.55 & 42 & 3.64 & 0.659 \\
\hline Increase of output capacity & 22 & 3.68 & 42 & 3.55 & 0.584 \\
\hline $\begin{array}{l}\text { Improvement of aspects related to health and } \\
\text { safety }\end{array}$ & 22 & 3.27 & 40 & 3.55 & 0.382 \\
\hline Reduction of environmental impact & 22 & 3.23 & 41 & 3.46 & 0.408 \\
\hline $\begin{array}{l}\text { Improvement of the aspects associated with } \\
\text { the rules and regulations of the foreign } \\
\text { market }\end{array}$ & 21 & 3.24 & 39 & 3.44 & 0.558 \\
\hline $\begin{array}{l}\text { Improvement of aspects associated with the } \\
\text { rules and regulations of the domestic market }\end{array}$ & 23 & 3.26 & 42 & 3.33 & 0.827 \\
\hline
\end{tabular}

* Scale: I = Very low.......5=Very high

Table 13. Contributions of innovation activity to small and large firms

Expansion of the range of products, entry into new markets, the firm's market share growth, and product quality improvement are the main impacts identified by the firms, regardless of their size.

It was also found that there are no significant differences between the intensities of the occurrences of the contributions when one compares the small and the large firms.

Table 14 shows the evolution of the indicators from 2002 to 2006. The values of the indicators of the dependent variable related to the evolution of the indicators of innovation performance for the group of firms participating in the survey are shown in terms of relative frequency (\%). 


\begin{tabular}{|l|l|l|l|l|l|l|l|}
\hline \multicolumn{2}{|c|}{ Indicators } & \multicolumn{3}{l}{$\begin{array}{l}\text { Intensity of the Evolution of the indicators in five years (202- } \\
\text { 2006) (\%) }\end{array}$} \\
\cline { 2 - 9 } & $\begin{array}{l}\text { NR } \\
\text { No } \\
\text { Response }\end{array}$ & $\begin{array}{l}\text { VLow } \\
(1)\end{array}$ & $\begin{array}{l}\text { Low } \\
(2)\end{array}$ & $\begin{array}{l}\text { Mean } \\
(3)\end{array}$ & $\begin{array}{l}\text { High } \\
(4)\end{array}$ & $\begin{array}{l}\text { VHigh } \\
(5)\end{array}$ & Total \\
\hline $\begin{array}{l}\text { Percentage of new products in total sales } \\
\text { Total number of technicians with } \\
\text { university degrees linked to the firm }\end{array}$ & 26.6 & 5.6 & 13.9 & 18.1 & 23.6 & 6.9 & 100 \\
\hline $\begin{array}{l}\text { Cost reduction resulting from } \\
\text { technological innovations to the process }\end{array}$ & 37.5 & 6.9 & 8.3 & 27.8 & 19.4 & 11.1 & 100 \\
\hline Number of patents obtained in Brazil & 50 & 2.8 & 16.7 & 20.8 & 16.7 & 5.6 & 100 \\
\hline Number of patents obtained abroad & 54.2 & 19.4 & 12.5 & 6.9 & 2.8 & 4.2 & 100 \\
\hline
\end{tabular}

Table 14. Evolution of the indicators of Innovation Performance (2002 to 2006) in decreasing order of intensity of occurrence

The evolution of the percentage of new products in total sales is an indicator with higher evolution intensity in the period being considered; it is followed by the total number of technicians with university degrees linked to the firm, and by the cost reduction percentage resulting from technological innovations to the process. The evolution of the indicators related to the granting of patents was insignificant. The data suggests that although the firms show signs that their competitiveness has increased, they do not register patents for reasons that call for more indepth investigation, such as cultural factors, legal issues, or, most probably, the costs, the bureaucracy and the very long time required to take out a patent.

Table 15 below shows the values of the variable related to the evolution of indicators, in a comparison of the firms by size. The values correspond to the mean value found (on a scale from I to 5) where the lowest value corresponds to the lowest intensity with which a source is used). To facilitate the analysis, the data are shown in decreasing order of intensity of use, the reference being the large firms.

\begin{tabular}{|l|l|l|l|l|l|}
\hline \multirow{2}{*}{ Indicators } & \multicolumn{4}{|c|}{ Intensity of the Evolution in five years 2002- } & 2006)(mean) \\
\cline { 2 - 5 } & \multicolumn{3}{|c|}{ Smaller } & \multicolumn{2}{c|}{ Larger } \\
\cline { 2 - 6 } & $\mathrm{N}$ & Mean & $\mathrm{N}$ & Mean & \\
\hline $\begin{array}{l}\text { Total number of technicians with } \\
\text { university degrees linked to the firm }\end{array}$ & 19 & 3.00 & 34 & 3.41 & 0.213 \\
\hline
\end{tabular}

(Continued on next page) 
(Continued from previous page)

\begin{tabular}{|l|l|l|l|l|l|}
\hline $\begin{array}{l}\text { Cost reduction resulting from } \\
\text { technological innovations to the process }\end{array}$ & 17 & 2.65 & 28 & 3.36 & $0.025^{*}$ \\
\hline Percentage of new products in total sales & 18 & 3.33 & 32 & 3.19 & 0.681 \\
\hline Number of patents obtained in Brazil & 9 & 1.78 & 27 & 2.52 & 0.158 \\
\hline Number of patents obtained abroad & 9 & 1.67 & 24 & 2.29 & 0.222 \\
\hline
\end{tabular}

Table 15. Comparative Evolution of the Innovation performance indicators (2002 to 2006), in decreasing order of intensity of occurrence, for large firms

The data in Table 15 suggest that the growth in the number of technicians with university degrees is the item with the highest intensity for the large firms, while the percentage of new products in total sales is the item with the highest intensity for the small firms. This suggests that the large firms enjoy a stronger numerical growth of resources, whereas the small firms enjoy stronger growth in terms of innovation. However, these differences are not significant. The only indicator showing a significant difference when one compares the small firms with the large ones is the cost reduction due to technological innovations to the process, which suggests that large firms are innovating significantly more in processes, which is consistent with the literature.

\section{Conclusions and recommendations}

The proposal of this study was to investigate some of the elements of the practices linked to the management of information sources for innovation purposes at firms and how they influence these firms' innovation performance, taking the size of the firms into account. Kinds of access to technology and the types of information sources for innovation were taken into account as elements of practices related to the management of information sources for the purposes of innovation. Measures associated with the impact on products, processes and technological training, as well as the behavior of evolution indicators of the results of innovations over time were taken into account as elements of innovation performance.

Concerning access to types of technology, we found that little emphasis is given to practices that focus on collaborative approaches with the external environment.
This is a worrisome finding, given the business world's current leaning towards open innovation models. In this respect, small firms showed significant differences vs. large firms, as the small firms give stronger emphasis to the practice of joining forums for the discussion of topics of their interest and to the associating themselves with other firms.

When one analyzes the types of sources of information for innovation activities, the results of the study indicate that the firms - analyzed as a group - focus strongly on R\&D as the chief source of information, the second most important source of information being visits to other affiliated firms. Other sources of technological information - albeit employed less strongly and in decreasing order are other departments of the firm, suppliers, trade fairs and expositions, and universities, among others. However, it is important to emphasize those sources of a more collective nature and that are outside the firm's context such as community networks and leading users - are practically ignored. When confronting the differences between large and small firms in regard to the intensity of use of different types of sources of technological information, we found that - although they do not differ much in terms of the intensity of use of the different types of innovation sources - large firms differ significantly from small firms in terms of the stronger use of practices related to visits to other firms and licensors, and to the practice of resorting to scientific/professional associations and to outsourced firms as sources of information for their technological innovations.

In relation to the results that concern the firms' innovation performance, we found that for all the indicators 
considered in our study, the intensity with which they occurred was quite high, with slightly more emphasis on the expansion of the range of products as a result of the innovation process. We did not find any significant differences in the performance indicators when we compared the large and small firms.

In addition to investigating the intensity with which firms enjoy the positive contributions to their business from innovation activities, we also investigated how several innovation performance indicators of the firms in the survey evolved over a five-year period. In this respect, though the firms did not show any significant evolution intensity, the indicator that measures the percentage of new products in total sales stood out due to having the highest intensity of use, while the indicator related to the number of patents in general and of foreign patents in particular was the least intense in terms of use. When comparing the small firms with the large ones in terms of the intensity of the evolution of these indicators, the evolution of the large firms was significantly higher than that of the small firms; however, no significant differences were found relative to the other indicators.

In short it was found that there is differences between small and big enterprises regarding the practices of managing external sources of innovation and the effects of these practices in the innovation performance, but only in a small number of aspects these differences can be considered statistically significant.

\section{References}

BABBIE, E. (1999) Métodos de pesquisa de survey. Editora da UFMG, Belo Horizonte.

BeltraMO, J., Mason, G., Paul, J. (2004) External knowledge sourcing in different national settings: A comparison of electronics establishments in Britain and France, Research Policy, v. 33, pp. 53-72.

BOONE, C., Carroll, G. R., Witteloostuijn, A. (2004) Size, differentiation and the performance of Dutch daily newspapers, Industrial and Corporate Change, v. I3, n. I, Pp. II7-I 48.
CHANDY, R. K., Tellis, G. J. (1998) Organizing for radical product innovation: the overlooked role of willingness to cannibalize, Journal of Marketing Research, Chicago, v. 35, n. 35, pp. 474-488.

CHATTERJI, D. (1996) Accessing external sources of technology, Research Technology Management, v. 39, pp. 4856.

CHEN, M-J., Hambrick, D. C. (1995) Speed, stealth, and selective attack: How small firms differ from large firms in competitive behavior, Academy of Management Journal, Briarcliff Manor, v. 38, n. 2; pp. 453-483.

COHEN, W. M., Levinthal, D. A. (1990) Absorptive capacity: a new perspective on learning and innovation, Administrative Science Quaterly, Ithaca, v. 35, n. I, Pp.I28I52, mar.

COSTA, V., Cunha, J. (200I) A universidade e a capacitação tecnológica das empresas, Revista de administração contemporânea, Curitiba, v. 5, n. I, Pp. 6I-8I, jan./abr.

DARSO, L. (200I) Innovation in the making. Denmark: Samfunds Litteratur.

FORD, D., Saren, M. (1996) Tecnology Strategy for Business. International Thomson Busines, Londres.

GREVE, H. R. (2008) A behavioral theory of firm growth: sequential attention to size and performance goals, Academy of Management Journal, Briarcliff Manor, v. 5I, n. 3, Pp. 476-494.

LEORNARD-BARTON, D. (1995) Wellsprings of knowledge: building and sustaining the sources of innovation. Harvard Business School Press, Boston.

LINDER, J. C., Jarvenpaa, S. L., Davenport, T. H. (2003) Innovation sourcing strategy matters, Accenture institute for strategic change. Cambridge, MA.

MACEDO, P. B. R., Albuquerque, E. M. (1999) P\&D e tamanho da empresa: evidência empírica sobre a indústria brasileira, Estudos Econômicos, v.29, n.3, pp. 343-365. 
McEVILY, B., Zaheer, A. (1999) Bridging ties: a source of firm heterogeneity in competitive capabilities, Strategic Management Journal, Chichester, v. 20, n. 12, p.p. II331156.

SBRAGIA, R., Andreassi, T., Kruglianskas, I. (1998) Os indicadores de P\&D\&E nas empresas mais e menos Innovadoras. In: Anais do XX Simpósio de Gestão da Inovação Tecnológica, São Paulo.

ZAHEER, A., BELL, G.G. (2005) Benefiting from network position: firm capabilities, structural holes and performance, Strategic Management Journal, Chichester, v. 26, n. 9, p.p. 809-826, sep. 